\title{
Penggunaan Akun Virtual Trading Dalam Edukasi Pasar Modal
}

\author{
Nugroho Wisnu Murti*1, Saptani Rahayu², Indriyana Widyastuti ${ }^{2}$ \\ ${ }^{1,2}$ Program Studi S1 Akuntansi, Program Studi S1 Manajemen, STIE AUB Surakarta \\ e-mail: "nugroho.wm@stie-aub.ac.id
}

\begin{abstract}
This community services activity (PKM) focuses on financial management education in diversifying investment in the capital market in the micro and small entrepreneur community around Surakarta (Solo). This activity based on 1) a lack of understanding of investment diversification in the capital market in this community; 2) the right moment to discuss this topic considering that the Indonesian capital market is undergoing restructuring after the Covid-19 pandemic. We started by material from representatives of the Indonesia Stock Exchange, followed by a simulation of share trading transactions by community services team and discussions. The interesting result of this activity is the transaction simulation method with a virtual account which is considered to be able to provide an easier understanding of the mechanism of buying and selling stock even though the initial individual has never known about stock at all. Although this activity is incidentally carried out only once, the outcome of this activity can be achieved by indicators of creating customer fund accounts.
\end{abstract}

Keywords: capital market, simulation, community services, micro-small entities

\begin{abstract}
Abstrak
Kegiatan pengabdian kepada masyarakat (PKM) ini fokus pada edukasi pengelolaan keuangan dalam diversifikasi investasi di pasar modal pada komunitas pengusaha mikro dan kecil di wilayah Surakarta (Solo) dan sekitarnya. Urgensi kegiatan ini mendasarkan pada dua pertimbangan yaitu 1) kurangnya pemahaman diversifikasi investasi di pasar modal pada komunitas tersebut; 2) momentum tepat untuk berdiskusi tentang topik ini mengingat pasar modal Indonesia sedang mengalami restrukturisasi setelah masa pandemic covid-19. Kegiatan dilakukan secara daring yang diawali dengan materi dari perwakilan Bursa Efek Indonesia, dilanjutkan dengan simulasi transaksi jual-beli saham oleh tim PKM serta diskusi. Hasil menarik kegiatan ini adalah metode simulasi transaksi dengan akun virtual yang dinilai mampu memberikan pemahaman secara lebih mudah tentang mekanisme transaksi jual beli saham meskipun untuk individu awalnya yang sama sekali belum pernah mengetahui tentang saham. Meskipun kegiatan ini secara insidental dilakukan hanya 1 kali, tetapi outcome kegiatan ini dapat dicapai dengan indikator pembuatan rekening dana nasabah (RDN).
\end{abstract}

Kata kunci: pasar modal, simulasi, pengabdian kepada masyarakat, EMKM

\section{PENDAHULUAN}

Artikel ini bertujuan untuk menyampaikan hasil dan proses edukasi tentang investasi pasar modal sebagai kegiatan Pengabdian Kepada Masyarakat (PKM). Kegiatan ini linier dengan salah satu tugas perguruan tinggi yang memiliki Galeri Investasi (GI) yang bekerjasama dengan Bursa Efek Indonesia. Selain itu, pertimbangan kegiatan ini juga mendasarkan pada analisis situasi pada komunitas pengusaha mikro kecil di Surakarta yang memberikan catatan penting tentang kebutuhan diversifikasi investasi keuangan pada komunitas tersebut. Analisis tersebut dilakukan dengan cara diskusi informal dengan sejumlah pengurus komunitas yang tergabung dalam ICSB (International Council for Small Business) Surakarta tentang berbagai macam instrumen investasi antara lain properti tanah dan bangunan, emas dan deposito serta pasar modal. Catatan penting pertama tentang diskusi tersebut adalah kurangnya pengetahuan tentang keamanan dan prospek investasi pada pasar modal. Catatan kedua, adalah aneka produk investasi yang ada pada pasar modal Indonesia dan bagaimana mekanisme pembelian dan penjualannya. Kedua catatan tersebut dapat digunakan sebagai bagian dari fenomena tentang aktivitas capital market di Indonesia yang masih belum terlalu dipahami bahkan masih diragukan. Sebagian besar anggota komunitas tersebut merasa lebih aman berinvestasi dalam deposito, tanah dan emas selain juga alasan mekanisme perdagangan di pasar modal yang belum terlalu dipahami. 
Persistensi Bursa Efek Indonesia (BEI) dalam meningkatkan partisipasi masyarakat semakin meningkat, dengan salah satunya diukur dari jumlah Galeri Investasi BEI di perguruan tinggi di berbagai wilayah Indonesia. Selain itu, masyarakat juga semakin mudah untuk dapat berpartisipasi dalam investasi di pasar modal yang tidak hanya nilai investasi yang semakin terjangkau tetapi juga kemudahan dalam membuat akun investasi. Sehingga kedua catatan yang kami sampai pada akhir paragraf pertama diatas, tugas perguruan tinggi yang memiliki Galeri Investasi. Kegiatan pengabdian kepada masyarakat dengan tema capital market mungkin sudah banyak dilakukan oleh perguruan tinggi khususnya yang memiliki Galeri Investasi ${ }^{1}$.

Namun publikasi tentang pelaksanaan kegiatan PKM dengan tema ini secara kuantitas masih memiliki ruang. Hal tersebut mendasarkan penelusuran yang dilakukan dengan menggunakan alat bantu publish or perish dengan strategi pencarian pada "title word" dan "keyword". kata kunci yang digunakan untuk penelusuran artikel yang ditunjukkan pada Tabel 1 yaitu "edukasi pasar modal" dan "pelatihan pasar modal" khusus pada title word. Penelusuran dilanjutkan dengan menggunakan kata "pasar modal" pada title word dan "pengabdian" pada key word". Dua kata kunci pencarian dengan tiga kata yang disatukan dalam tanda petik tersebut mungkin dinilai cukup panjang. Dampaknya akan semakin membatasi jumlah artikel yang akan ditemukan. Langkah tersebut mempertimbangkan tujuan untuk menemukan artikel ilmiah topik pasar modal yang fokus pada kegiatan PKM yaitu dengan menggunakan kata "edukasi" dan pelatihan" sebagaimana kegiatan yang mendasari penyusunan artikel ini.

Tabel 1. Ringkasan Hasil Penelusuran Artikel Topik PKM Bidang Edukasi Pasar Modal

\begin{tabular}{|c|c|c|c|c|c|c|c|}
\hline \multirow[b]{2}{*}{ No } & \multicolumn{2}{|c|}{$\begin{array}{l}\text { Kata kunci yang digunakan } \\
\text { untuk penelusuran refrensi }\end{array}$} & \multirow[b]{2}{*}{$\begin{array}{c}\text { Jumlah } \\
\text { publikasi } \\
\text { yang } \\
\text { ditemukan }\end{array}$} & \multicolumn{4}{|c|}{ Kategori publikasi } \\
\hline & $\begin{array}{c}\text { Berdasar } \\
\text { "title } \\
\text { word" }\end{array}$ & $\begin{array}{l}\text { Berdasar } \\
\text { "key word" }\end{array}$ & & Penelitian & $\begin{array}{l}\text { Pengabdian } \\
\text { Masyarakat }\end{array}$ & $\begin{array}{c}\text { Lainnya } \\
\text { (skripsi, } \\
\text { e-book, } \\
\text { dan } \\
\text { working } \\
\text { paper) }\end{array}$ & $\begin{array}{c}\text { Publication } \\
\text { dan publisher } \\
\text { tidak } \\
\text { terdeteksi } \\
\text { saat } \\
\text { penelusuran }\end{array}$ \\
\hline 1. & $\begin{array}{l}\text { "pasar } \\
\text { modal" }\end{array}$ & "pengabdian" & 97 & $\begin{array}{c}6 \\
(15 \%)\end{array}$ & $\begin{array}{c}33 \\
(85 \%)\end{array}$ & 22 & 36 \\
\hline 2. & $\begin{array}{c}\text { "pelatihan } \\
\text { pasar } \\
\text { moldal" }\end{array}$ & - & 33 & $\begin{array}{c}11 \\
(61 \%)\end{array}$ & $\begin{array}{c}7 \\
(39 \%)\end{array}$ & - & 15 \\
\hline 3. & $\begin{array}{c}\text { "edukasi } \\
\text { pasar } \\
\text { modal" }\end{array}$ & - & 22 & $\begin{array}{c}10 \\
(63 \%)\end{array}$ & $\begin{array}{c}6 \\
(37 \%)\end{array}$ & - & 6 \\
\hline \multicolumn{3}{|c|}{ Jumlah } & 152 & 27 & 46 & 22 & 57 \\
\hline \multicolumn{3}{|c|}{ Penggabungan } & & $\begin{array}{c}13 \\
(24 \%) \\
\end{array}$ & $\begin{array}{c}42 \\
(76 \%) \\
\end{array}$ & & \\
\hline
\end{tabular}

Sumber: software penelusuran artikel publish or perish 7 dengan batasan kata kunci sebagaimana yang ditunjukkan pada table dan dilakukan pada tanggal 10 Mei 2021.

Kami membatasi penelusuran artikel ilmiah hanya pada publikasi yang diterbitkan oleh jurnal ber ISSN dan prosiding yang digunakan sebagai referensi termasuk melakukan exclude pada artikel yang dengan publisher yang tidak dapat dideteksi dari search engine yang digunakan. Berdasarkan 3 tahap penelusuran tersebut, terdapat beberapa artikel yang sama sehingga total penelusuran berdasar 3 tahap tersebut sebanyak 55 artikel yang terdiri dari 42 artikel PKM dengan tema pasar modal dan 13 artikel penelitian dengan tema pasar modal yang didasarkan pada kegiatan PKM dengan bidang pasar modal. Temuan menarik pertama atas penelusuran tersebut adalah terkait dengan sejumlah artikel penelitian bidang pasar modal yang dipublikasikan berdasarkan kegiatan PKM berupa pelatihan tentang pengetahuan pada pasar modal antara lain (Aditama \& Nurkhin, 2020; Cahyani et al., 2020; Listyani et al., 2019; Oktavia et al., 2020; Putra \& Supadmi, 2019; Wibowo \& Purwohandoko, 2019). Temuan ini dapat menjadi

${ }^{1}$ Daftar Galeri Investasi BEI diperguruan tinggi dapat diakses pada alamat web berikut https://www.idx.co.id/media/9762/20210331-database-gibei.pdf 
referensi bahwa efektivitas pendidikan pasar modal yang dijalankan oleh Galeri Investasi di perguruan tinggi secara ilmiah dapat diuji.

Temuan menarik lain adalah desain riset eksperimen yang menunjukkan efektivitas edukasi pasar modal untuk meningkatkan minat berinvestasi oleh (Dewi, 2020). Temuan ini semakin memperkuat bahwa model pendidikan pasar modal dalam penelusuran artikel ini sebagian besar memberikan kesimpulan yang positif tentang efektifitas pendidikan tentang pasar modal. Akan tetapi, perlu diperhatikan juga tentang peserta yang menerima pendidikan. Beberapa temuan efektifitas edukasi pendidikan pasar modal diatas dilakukan pada lingkungan pendidikan antara lain kepada siswa, guru dan bahkan mahasiswa yang juga dilakukan oleh (Merawati \& Putra, 2015; Putra \& Supadmi, 2019). Sementara itu, artikel ini focus pada pengusahaa perorangan yang pada level Usaha Mikro Kecil. Sebagaimana dijelaskan diatas bahwa pemilihan obyek ini mendasarkan pada kurangnya pemahaman dan kebutuhan bagaimana memahami untuk berinvestasi di pasar modal secara lebih sederhana.

Pelaksanaan PKM yang menjadi dasar penyusunan artikel ini menunjukkan proses edukasi menggunakan media simulasi dengan virtual akun yang harapannya memberikan gambaran secara lebih riil kepada calon investor terutama kepada yang belum memiliki akun RDN. Hal ini yang belum banyak dilakukan dalam beberapa penelusuran kegiatan PKM yang dipublikasikan antara lain (Mawardi \& Lemiyana, 2020; Sandri et al., 2018; Septiani et al., 2020; Wardhani \& Widyaningrum, 2020). Beberapa laporan kegiatan PKM tersebut focus pada edukasi dalam bentuk sosialisasi. Kami berpendapat bahwa meskipun edukasi pasar modal dilakukan pada tahap awal, tetapi simulasi transaksi yang dilakukan sendiri oleh peserta tidak hanya akan mempermudah memahami mekanisme yang berjalan dalam pasar modal secara riil, tetapi peserta juga akan merasakan sensasi awal tentang bagaimana melakukan transaksi jual beli saham. Meskipun menggunakan akun simulasi, tetapi dinamika pasar secara riil time akan memberikan ruang secara langsung kepada peserta untuk memasuki pasar modal secara riil. Artikel PKM tentang penggunaan simulasi trading dalam pelatihan analisis fundamental dan teknikal dapat ditunjukkan dari (Andari \& Setianingsih, 2017). Akan tetapi level pelatihan ini lebih cenderung pada peserta yang telah memiliki akun investasi ataupun yang masih mengalami kesulitan dalam melakukan screening terhadap investasi saham.

Selain gap yang masih ditemukan berdasarkan desain pelatihan atau edukasi bidang pasar modal yang ditunjukkan pada beberapa artikel PKM diatas, gap tentang peserta edukasi juga ditemukan. Banyak ditemukan artikel PKM tentang kegiatan edukasi pasar modal yang dilakukan pada lingkungkungan pendidikan seperti siswa, guru dan mahasiswa antara lain (Aspirandi \& Oktavian, 2019; Badriatin et al., 2020; Isbanah et al., 2017; Ismail, 2020). Kegiatan PKM pasar modal yang sebagian besar diadakan pada lingkungan pendidikan diatas juga diimbangi dengan adanya program Bursa Efek Indonesia untuk membuka kegiatan edukasi secara terstruktur sebagai binaan Galeri Investasi di perguruan tinggi dengan nama Galeri Edukasi. Jenis galeri baru tersebut dapat didirikan salah satunya pada sekolah menengah atas atau kejuruan. Sementara itu, kami kembali fokus pada edukasi kepada masyarakat yang bersifat umum, diluar lingkungan pendidikan dan memiliki potensi besar untuk masuk di pasar modal harapan kapitalisasi yang lebih besar yaitu komunitas pengusaha mikro dan kecil di wilayah Surakarta.

\section{METODE}

Seluruh rangkaian kegiatan PKM ini dilakukan secara online baik dari proses pendaftaran maupun sampai dengan tahap evaluasi capaian workshop. Kertas kerja workshop ini juga disediakan secara online dengan aplikasi yang dapat diunduh secara gratis dalam aplikasi yang berbasis android (RTI business). Dengan demikian peserta workshop ini membutuhkan handphone sebagai alat bantu mengerjakan kertas kerja yang digunakan sebagai salah satu indikator capaian PKM. Alur pelaksanaan workshop termasuk perangkat yang dibutuhkan oleh peserta PKM dapat ditunjukkan pada Gambar 1. Terdapat beberapa catatan yang dapat menjelaskan tentang gambar tersebut antara lain tentang Link Video tutorial yang dari youtube Channel Galeri Investasi AUB Surakarta, memateri workshop dan indikator capaian pelaksanaan PKM dalam bentuk workshop ini.

Berdasar alur rangkaian kegiatan PKM yang ditunjukkan pada Gambar 1, secara rinci proses pelaksanaan workshop sehari dapat ditunjukkan pada Tabel 2. Materi pertama adalah materi yang terkait dengan pengantar pasar modal yang disampaikan dari perwakilan Bursa Efek Indonesia. Sementara itu, 
materi kedua dilakukan secara hands-on dimana peserta melakukan transaksi beli dan jual saham kode tertentu untuk one-day clear.

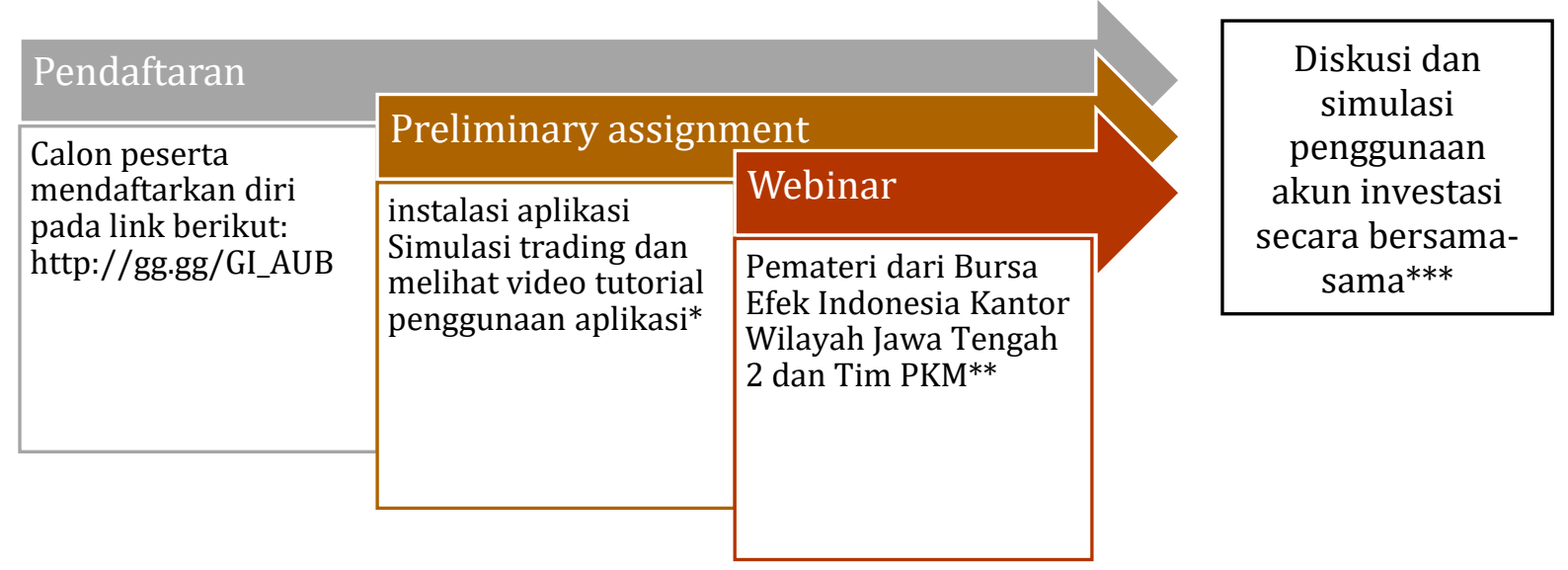

Gambar 1. Rangkaian Kegiatan Pengabdian Kepada Masyarakat

* Aplikasi yang digunakan dalam simulasi trading dan Investasi adalah RTI Bussines berbasis android. Tim PKM menyediakan video tutorial penggunaan aplikasi tersebut yang dapat diakses pada link video youtube

** Dua pemateri workshop pada kegiatan PKM ini terdiri dari 2 narasumber:

1. M Wira Adibrata Kepala Kantor Perwakilan Bursa Efek Indonesia Jawa Tengah 2

2. Nugroho Wisnu Murti Direktur Galeri Investasi STIE AUB sekaligus tim PKM

*** Indikator workshop sehari kegiatan PKM, khususnya pada penggunaan aplikasi simulasi adalah kegiatan peserta dalam melakukan jual-beli saham selama durasi workshop dengan akun masingmasing dengan rincian sebagai berikut:

1. Peserta berhasil membeli atau mendapatkan saham $\rightarrow$ posisi "match"

2. Peserta mulai memperhatikan untuk mendapatkan saham yang murah berdasarkan daily transaksi diukur dengan frekuensi melakukan "Amend".

Tabel 2. Rincian Pelaksanaan Wokshop Selasa, 28 Juli 2020

\begin{tabular}{rlc}
\hline $\mathbf{I o}$ & \multicolumn{1}{c}{ Rincian Kegiatan } & aktu yang dibutuhkan \\
\hline 1 & Pembukaan & 5 menit \\
2 & Penyampaian materi Peluang investasi di pasar modal Indonesia & 35 menit \\
3 & Penyampaian materi Galeri Investasi Perguruan Tinggi adalah terbuka & 40 menit \\
& untuk umum dan belajar dari simulasi transasksi perdagangan efek & \\
& dengan akun virtual investasi yang disampaikan oleh Tim PKM & 20 menit \\
4 & Diskusi & 20 Menit \\
5 & Kuis dan Penutupan & \\
\hline
\end{tabular}

Sumber: Rincian pelaksanaan workshop kegiatan PKM Peluang Investasi Di Pasar Modal Indonesia Dan Program Pendidikannya Di Perguruan Tinggi

\section{HASIL DAN PEMBAHASAN}

Capaian kegiatan PKM ini diukur dengan beberapa indikator antara lain 1) jumlah peserta dan komposisinya; 2) Aktivitas peserta dalam penyelesaian kertas kerja dan 3) tingkat kepuasan peserta pada kegiatan PKM ini. Secara terperinci, capaian setiap indikator dapat dijelaskan sebagai berikut:

1. Capaian jumlah peserta

Analisa capaian pada indikator ini dapat dilakukan dengan membandingkan antara jumlah peserta yang mendaftar dengan jumlah peserta yang datang pada kegiatan PKM. Sebagaimana dijelaskan pada bagian pendahuluan bahwa kegiatan PKM secara khusus bekerja sama dengan asosiasi pengusaha mikro dan kecil di area Surakarta yang tergabung dalam ICSB (International Council for Small Business). Akan tetapi tidak menutup kemungkinan bahwa kegiatan ini diikuti oleh pihak diluar ICSB, misalkan masyarakat umum yang juga sebagai pengusaha mikro dan kecil yang tidak tergabung dalam 
asosiasi tersebut. Dengan demikian beberapa pihak yang terlibat dalam kegiatan PKM ini ditunjukkan pada Tabel 3. Untuk mempermudah memberikan informasi pelaksanaan workshop ini, kami juga membuat flyer yang juga memuat link pendaftaran workshop. Jumlah peserta workshop ini sebanyak 96 orang dari batasan kuota peserta sebanyak 100 orang. Batasan ini mempertimbangkan efektifitas dalam proses pelaksanaan hand-on yang diperkirakan akan banyak diskusi dan pertanyaan dari peserta, karena peserta melakukan kegiatan jual beli saham secara langsung. Dengan demikian berdasarkan efektifitas peserta, capian kegiatan PKM ini adalah $96 \%$.

Tabel 3. Pihak yang terlibat dalam PKM

\begin{tabular}{|c|c|c|c|}
\hline No & Pihak yang terlibat & Peran & Flyer \\
\hline 1. & $\begin{array}{l}\text { Tim PKM dari P3M } \\
\text { STIE AUB }\end{array}$ & $\begin{array}{l}\text { Memfasilitasi pelasanaan PKM } \\
\text { workshop }\end{array}$ & kpei \\
\hline 2. & $\begin{array}{l}\text { Surakarta } \\
\text { International } \\
\text { Council for Small } \\
\text { Business (ICSB) }\end{array}$ & Peserta utama kegiatan PKM & $\begin{array}{l}\text { NESIA } \\
\text { N TINGGI }\end{array}$ \\
\hline 3. & $\begin{array}{l}\text { Kelompok Studi } \\
\text { Pasar Modal } \\
\text { (KSPM) STIE AUB }\end{array}$ & $\begin{array}{l}\text { Sejumlah mahasiswa yang } \\
\text { membantu tim PKM dalam } \\
\text { pelaksanaan workshop }\end{array}$ & \\
\hline 4. & $\begin{array}{l}\text { Galeri Investasi } \\
\text { STIE AUB }\end{array}$ & $\begin{array}{l}\text { Menyediakan jaringan internet } \\
\text { dan diskusi dalam merimusakan } \\
\text { kerta kerja dalam pelaksanaan }\end{array}$ & E III \\
\hline 5. & $\begin{array}{l}\text { Bursa Efek } \\
\text { Indonesia (BEI) }\end{array}$ & Menyediakan Pemateri & 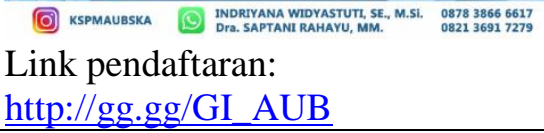 \\
\hline
\end{tabular}

2. Aktifitas peserta dalam mengerjakan kertas kerja.

Aktifitas peserta diukur dengan dua indikator yaitu pertama diskusi atau pertanyaan yang disampaikan dari peserta kepada pemateri dan kedua, adalah dari tingkat aktivitas dalam mengerjakan kertas kerja transaksi jual beli saham secara online. Untuk mempermudah pelaksanaan simulasi transaksi secara bersama ini, tim PKM menyediakan video pembelajaran yang saat ini dapat dilihat pada link youtube ${ }^{2}$. Video tersebut berdurasi sekitar 20 menit yang berisi tentang tutorial menggunakan aplikasi RTI Business untuk simulasi trading (jual dan beli) saham secara online, secara real time mengikuti fluktuasi harga saham di pasar modal Indonesia. Cuplikan atas tampilan Video tersebut ditunjukkan pada Gambar 2. Selain itu, Gambar dua juga menunjukkan beberapa tampilan kertas kerja dengan menggunakan aplikasi RTI atas hasil kerja peserta dalam mengikuti workshop.

Dokumentasi secara online dalam kegiatan PKM ini ditunjukkan pada Gambar 3. Beberapa pertanyaan yang kami nilai baik dari peserta antara lain: 1) asumsi yang digunakan dalam penggunaan aplikasi simulasi trading (apakah ada perbedaaan dengan pergerakan saham yang sesungguhnya); 2) bagaimana pembeli saham yang baik untuk saham pertama kita; 3) bagaimana mengatur keuangan dalam membeli saham; dan 4) Bagaimana uang atas keuntungan jual beli saham dapat diambil.

\footnotetext{
${ }^{2}$ Video link youtube : https://www.youtube.com/watch?v=LZxpqiORJpU
} 


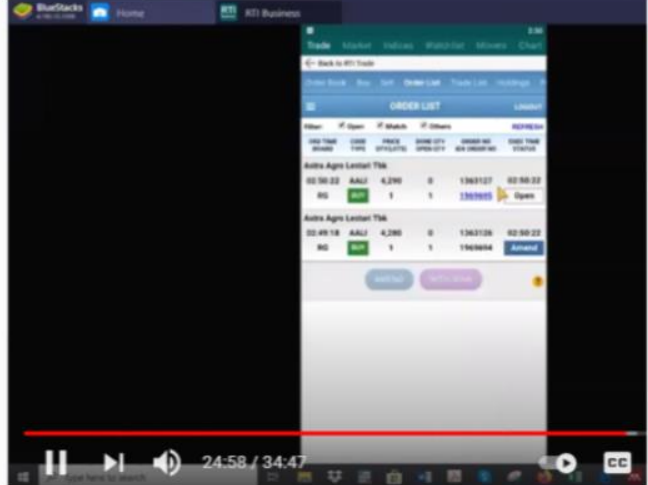

Penggunaan Virtual Trading RT

\begin{tabular}{lr}
\hline BROKER NAME : & ID - IDX Sekuritas \\
\hline ACCOUNT NO : & \\
ACCOUNT NAME : & NIKOLASCHRISMANA \\
\hline BUYING POWER (RP) & 0 \\
\hline TOTAL BUY (RP) & $98,810,000$ \\
\hline TOTAL SELL (RP) & 0 \\
\hline TOTAL BOUGHT (RP) & $1,190,000$ \\
\hline TOTAL SOLD (RP) & $100,000,000$ \\
\hline INITIAL BALANCE (RP) & $98,810,000$ \\
\hline CASH (RP) & \\
\hline
\end{tabular}

\begin{tabular}{|c|c|c|c|c|c|}
\hline Trade & Market & Indic & \multicolumn{2}{|c|}{ Watchlist } & vers \\
\hline \multicolumn{6}{|c|}{$<$ Back to RTI Trade } \\
\hline Prder Book & ok Buy & Sell & Order List & \multicolumn{2}{|c|}{ Trade List } \\
\hline$\equiv$ & \multicolumn{3}{|c|}{ ORDER LIST } & \multicolumn{2}{|c|}{ LOGOUT } \\
\hline \multicolumn{6}{|c|}{ Sawit Sumbermas Sarana Tbk. } \\
\hline $0: 26: 27$ & ssMS & 905 & 7 & 2538215 & 10: \\
\hline RG & BUY & 7 & 0 & 3535851 & $M=$ \\
\hline \multicolumn{6}{|c|}{ jummarecon Agung Tbk } \\
\hline $0: 25: 59$ & SMRA & 1,000 & 9 & 2538208 & 10:: \\
\hline RG & BUY & 9 & 0 & 3535844 & Ma \\
\hline
\end{tabular}

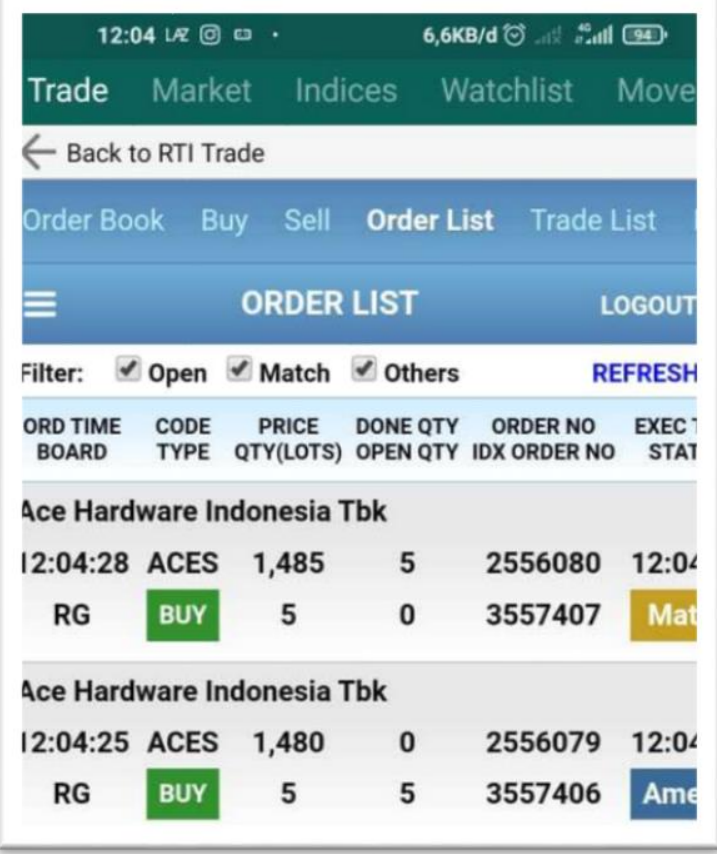

\section{Gambar 2. Sebagian tampilan dari penggunaan akun RTI oleh peserta}

3. Tingkat Kepuasan peserta dan saran untuk kegiatan beikutnya.

Penilaian kepuasan peserta atas kegiatan ini diobservasi secara online dengan mengisi kuesioner sekaligus presensi dengan link berikut_http://tiny.cc/presensi_webinarGI2020. Pertanyaan dan hasil terkait dengan tingkat kepuasan tersebut ditunjukkan pada Tabel 4. Secara keseluruhan sebanyak 68,3\% peserta menganggap bahwa rangkaian acara workshop ini menarik, dan 26,9\% beranggapan bahwa acara ini sangat menarik. Sementara itu sebanyak $4,8 \%$ peserta menganggap bahwa acara ini secara keseluruhan cukup menarik. Capaian ini merepresentasikan efektivitas pelaksanaan pengabdian dari ukuran kepuasan peserta webinar. Informasi yang menarik dari peserta tentang usulan kegiatan PKM berikutnya yang diminta kepada kami.

Evaluasi kepuasan juga kami lakukan dengan meminta usulan tema kegiatan berikutnya yang dibutuhkan dari komunitas pengusaha mikro kecil ini. Terdapat 87 usulan dari 96 peserta. Identifikasi dilakukan dengan mengelompokkan usulan tersebut dalam 5 kelompok usulan antara lain 1) analisis investasi; 2) diversifikasi instrumen Investasi; 3) meningkatkan efektifitas kinerja EMKM; 4) manajemen SDM dalam usaha kecil mikro dan kecil; 5) perpajakan atas investasi. 
Tabel 4. Tingkat kepuasan peserta kegiayan PKM

\begin{tabular}{lll}
\hline No Pertanyaan & Keterangan \\
\hline 1. Apakah materi yang di berikan telah & Sangat Sesuai \\
sesuai dengan harapan anda? & Cukua \\
2. Tidak Sesuai \\
Bagaimana tanggapan anda tentang \\
penjelasan para Nara Sumber dalam \\
menyampaikan materinya, \& interaksi \\
dalam menjawab pertanyaan?
\end{tabular}

Sumber : Output google form atas presensi dan kuesioner kepuasan peserta workshop atas kegiatan PKM pada tanggal 28 Juli 2020
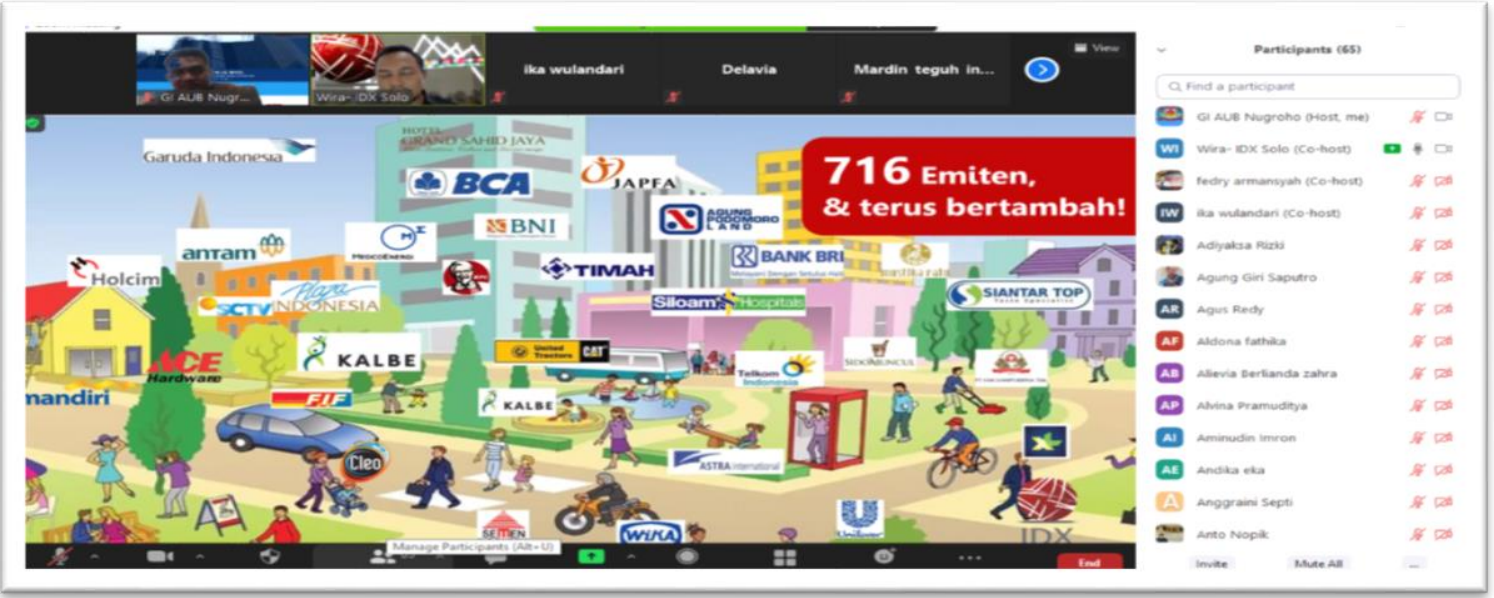

(a) Dokumentasi saat penyampaian materi 


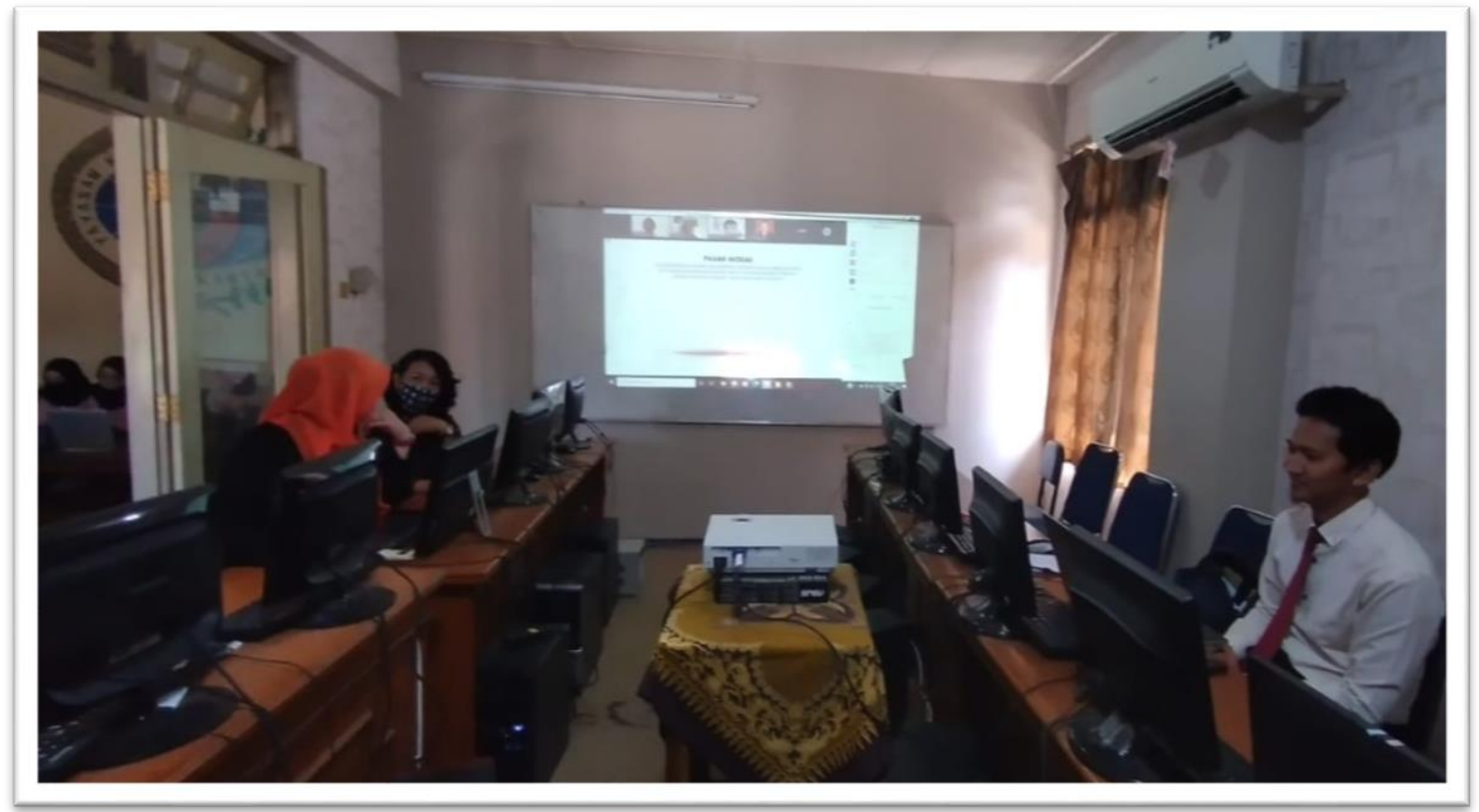

(b) Dokumentasi tim PKM saat berjalannya kegiatan

Gambar 3. Dokumentasi

\section{KESIMPULAN}

Publikasi kegiatan pengabdian kepada masyarakat ini mendasarkan pada dua pertimbangan. Pertama adalah komunikasi dengan komunitas pengusaha mikro kecil yang tergabung dalam asosiasi International Council for Small Business (ICSB) tentang money manajemen khususnya mengatur keuangan untuk tujuan investasi. Tim PKM menangkap komunikasi ini dengan mengusulkan kegiatan literasi investasi di pasar modal, yang ternyata belum sepenuhnya dipahami oleh anggota asosiasi. Pertimbangan kedua adalah publikasi tentang pengabdian tentang tema pasar modal yang masih sedikit dapat ditemukan berdasarkan penelusuran melalui software Publish or perish 7 dengan kata pencarian "pengabdian" pada judul dan "pasar modal" pada key word. Dengan demikian, publikasi kegiatan PKM dengan tema pasar modal dengan beberapa indikator dan proses ini harapannya dapat digunakan sebagai bahan pertimbangan khususnya pada perumusan kegiatan PKM dengan tema yang sejenis.

Secara keseluruhan target kegiatan ini dapat dapat tercapai. Indikator pertama capaian tersebut adalah jumlah peserta yang tercapai $96 \%$ dari batas maksimal peserta sebanyak 100 peserta. Berdasarkan indikator aktivitas diskusi peserta, tidak semua peserta melakukan transaksi secara bersama saat workshop, tetapi sebagian besar peserta memahami dan telah mencoba melakukan transaksi jual dan beli saham secara real time saat work sebagaimana salah satu hasilnya ditunjukkan pada Gambar 2. Selain itu, tim PKM juga telah menyediakan link youtube yang merupakan produk PKM yang dapat diakses setiap saat oleh peserta jika menginginkan untuk kembali belajar investasi yang dimulai dari akun simulasi. Capaian terakhir adalah tingkat kepuasan peserta. Secara keseluruhan peserta menilai bahwa kegiatan ini baik sampai dengan sangat baik. Selain itu, kegiatan ini juga mengidentifikasi beberapa usulan dari peserta tentang kegiatan PKM yang akan datang dalam 5 kelompok tema antara lain : 1) analisis investasi; 2) diversifikasi instrumen Investasi; 3) meningkatkan efektifitas kinerja EMKM; 4) manajemen SDM dalam usaha kecil mikro dan kecil; 5) perpajakan atas investasi.

\section{DAFTAR PUSTAKA}

Aditama, R. R., \& Nurkhin, A. (2020). Pengaruh Pelatihan Pasar Modal Terhadap Minat Investasi Mahasiswa Di Pasar Modal Dengan Pengetahuan Investasi Dan Manfaat Investasi Sebagai Variabel Intervening. Business and Accounting Education Journal, 1(1), 27-42.

Andari, A. T., \& Setianingsih, N. A. (2017). Pelatihan Pasar Modal Menggunakan Analisis Fundamental dan Teknikal di Kelurahan Tinalan Kota Kediri. Jurnal Pengabdian Pada Masyarakat INDEKS (Ilmu 
Pengetahuan Dan Teknologi Terintegrasi), 2(1).

Aspirandi, R. M., \& Oktavian, D. D. (2019). Pelatihan Pasar Modal Syariah Pada SMK Al Hasan Panti Jember. Jurnal Pengabdian Masyarakat IPTEKS, 5(1), 66-71.

Badriatin, T., Rinandiyana, L. R., \& Sudiarti, S. (2020). Pelatihan Investasi Sejak Dini Melalui Pasar Modal Pada Mahasiswa Baru Politeknik Triguna Tasikmalaya. JCES (Journal of Character Education Society), 3(1), 8-16.

Cahyani, D. I., Diana, N., \& Mawardi, M. C. (2020). Analisis Strategi Sosialisasi Pasar Modal Dan Pengaruhnya Terhadap Keputusan Berinvestasi Di Pasar Modal (Studi Pada Mahasiswa Di Kota Malang). Jurnal Ilmiah Riset Akuntansi, 9(10), 94-103.

Dewi, P. (2020). Pengaruh Edukasi Pasar Modal Terhadap Persepsi Risiko Dan Minat Berinvestasi Masyarakat. KRISNA: Kumpulan Riset Akuntansi, 12(1), 129-138.

Isbanah, Y., Musdholifah, Hartono, U., \& Budiono. (2017). Pelatihan Pasar Modal dan Trading Stock sebagai Upaya Peningkatan Keterampilan Guru-Guru Ekonomi SMA di Surabaya. Dedication: Jurnal Pengabdian Masyarakat, 1(1).

Ismail, J. (2020). Edukasi Dan Motivasi Menjadi Investor Di Pasar Modal Syariah (Studi Kasus Galeri Investasi Syariah Iain Sultan AMAI). BALANCA: Jurnal Ekonomi Dan Bisnis Islam, 2(2).

Listyani, T. T., Rois, M., \& Prihati, S. (2019). Analisis Pengaruh Pengetahuan Investasi, Pelatihan Pasar Modal, Modal Investasi Minimal Dan Persepsi Risiko Terhadap Minat Investasi Mahasiswa Di Pasar Modal (Studi Pada PT Phintraco Sekuritas Branch Office semarang). Jurnal Aktual Akuntansi Keuangan Bisnis Terapan (AKUN BISNIS), 2(1), 49-70.

Mawardi, M., \& Lemiyana, L. (2020). Edukasi Pasar Modal Syariah untuk Menumbuhkan Minat Investasi bagi Mahasiswa UIN Raden Fatah Palembang. Jurnal Pengabdian Pada Masyarakat, 5(2), 529-537.

Merawati, L. K., \& Putra, I. P. M. J. S. (2015). Kemampuan pelatihan pasar modal memoderasi pengaruh pengetahuan investasi dan penghasilan pada minat berinvestasi mahasiswa. Jurnal Ilmiah Akuntansi Dan Bisnis, 10(2), 108-118.

Oktavia, S. A., Mu'ayanah, R., \& Hana, K. F. (2020). Pengaruh Edukasi, Manfaat, Rekomendasi Pasar Modal Syariah Terhadap Minat Berinvestasi Mahasiswa Febi Iain Kudus. BanKu: Jurnal Perbankan Dan Keuangan, 1(2), 75-84.

Putra, I., \& Supadmi, N. L. (2019). Pengaruh Pelatihan Pasar Modal, Persepsi Mahasiswa, Modal Minimal dan Hubungan Pertemanan pada Minat Berinvestasi. E-Jurnal Akuntansi, 27(2).

Sandri, S. H., Samsiah, S., \& Bakaruddin. (2018). Edukasi Pasar Modal Di Madrasah Aliyah Muhammadiyah Pekanbaru. Jurnal Pengabdian Untukmu Negeri, 2(1), 1-4.

Septiani, D., Martono, A., Ferdiansyah, \& Karlina, L. (2020). Pengenalan Manajemen Investasi Dan Pasar Modal Bagi Siswa/I Dan Guru Akuntansi SMK Bintang Nusantara. JURNAL KUAT: Keuangan Umum Dan Akuntansi Terapan, 2(1), 58-63.

Wardhani, D. P., \& Widyaningrum, P. W. (2020). Edukasi Dan Pelatihan Investasi Pasar Modal Indonesia Di Kelurahan Sukorejo. BUDIMAS: Jurnal Pengabdian Masyarakat, 2(2), 100-108.

Wibowo, A., \& Purwohandoko. (2019). Pengaruh Pengetahuan Investasi, Kebijakan Modal Minimal Investasi, Dan Pelatihan Pasar Modal Terhadap Minat Investasi (Studi Kasus Mahasiswa FE Unesa Yang Terdaftar Di Galeri Investasi FE UNESA). Jurnal Ilmu Manajemen (JIM), 7(1), 192-201. 